\title{
Does voter polarisation induce party extremism? The moderating role of
}

\author{
abstention \\ Philipp Dreyer ${ }^{a^{*}}$ and Johann Bauer ${ }^{\mathrm{b}}$ \\ ${ }^{a}$ European Institute, London School of Economics and Political Science; ${ }^{b}$ Department of \\ Mathematics, City, University of London; *Corresponding author p.dreyer@1se.ac.uk \\ European Institute, Cowdray House, Houghton Street, London WC2A 2AE
}

\begin{abstract}
Notes on contributors:
Philipp Dreyer is a PhD candidate in the European Institute at the London School of Economics and Political Science. His doctoral research focuses on parties' election strategies, mass-elite linkages in Western Europe, and the consequences of partisan attachments. [p.dreyer@lse.ac.uk]
\end{abstract}

Johann Bauer is a $\mathrm{PhD}$ candidate in the Mathematics Department at City, University of London. His doctoral research focuses on evolutionary game theoretic approaches to distributed optimisation problems. [johann.bauer@city.ac.uk]

This article contributes to the literature on representation by examining how the ideological polarisation of the electorate affects parties' programmatic positions in multiparty systems. The main argument is that parties face incentives to adopt more extreme positions when the electorate becomes more ideologically polarised and the share of non-moderate voters is higher. The reason is that by adopting moderate positions parties will prompt their non-moderate core constituents to sit out the election. This risk is conditioned by voters' propensity to abstain. A higher (lower) propensity to abstain means that parties alienate a larger (smaller) share of their core constituents when adopting a moderate position. Parties therefore respond to greater voter polarisation by adopting more extreme positions, but the effect declines as voters' propensity to abstain decreases. An empirical analysis of parties' programmatic positions in eleven Western European countries between 1977 and 2016 strongly supports this expectation.

Key words: representation; party competition; abstention; voter polarisation

Acknowledgements: The authors would like to thank Sara Hobolt, Sara Hagemann, Jim Adams, Laura Stoker, Julian Hoerner, Lawrence Ezrow, Valentino Larcinese, Diane Bolet, Björn Bremer, Tom Louwerse, and the anonymous reviewers for useful comments and advice. 


\section{Introduction}

What is the influence of voters' ideological polarisation on parties' programmatic positions in multiparty democracies? Recent theoretical and empirical work suggests that parties adopt more extreme positions when voters are more ideologically polarised (Cox 1990; Merrill and Adams 2002; Ezrow 2007). The findings are given a positive interpretation insofar as a central function of parliaments is to represent the diversity of public opinion (Pitkin 1967). While scholars of representation often emphasise the primacy of the median voter, Cox (1997) argues instead that the representative process should be judged by the degree to which voters can find representatives who advocate similar preferences. If parties predominantly adopt centrist positions that appeal only to the median voter, voters with non-centrist ideological preferences are not adequately represented. From a normative perspective, the menu of ideological alternatives in a given country should thus increase with the ideological polarisation of the electorate (Andrews and Money 2009).

Despite increased scholarly interest in the causes of party system dispersion (see Ezrow 2008; Dalton 2008; Andrews and Money 2009; Dow 2011; Curini and Hino 2012; Matakos, et al. 2016; Fenzl 2018), evidence that parties' programmatic positions respond to the ideological polarisation of the electorate is limited. The few empirical studies that investigate the relationship between party positioning and voter polarisation present contrasting results. Ezrow (2007) shows that changes in party system dispersion on a dominant left-right dimension correlate with corresponding changes in the ideological polarisation of the electorate (see also Adams et al. 2012a). In contrast, Dalton (2008) finds no evidence that party system dispersion is affected by voters' ideological polarisation (see also Adams et al. 2012b).

This article contributes to the debate by arguing that the effect of voter polarisation on parties' policy positions is conditioned by voters' propensity to abstain. We argue that when the electorate becomes more ideologically polarised, parties increasingly face the risk that 
moderate policy positioning will alienate their non-moderate core constituents. The reason is that higher voter polarisation increases the share of core constituents with non-moderate ideological preferences. Vote losses from alienated core constituents might be offset by vote gains from moderate swing voters, but this depends on voters' propensity to abstain. A high propensity to abstain means that parties are unable to retain the support of their core constituents when adopting a moderate policy position, whereas a low propensity to abstain reduces the risk of alienating core constituents. Consequently, parties are expected to adopt more extreme policy positions when the electorate becomes more ideologically polarised, but the effect declines as voters' propensity to abstain decreases.

We test our arguments empirically by analysing parties' left-right positions in eleven Western European countries between 1977 and 2016. In accordance with previous research, we rely on Comparative Manifesto Project (CMP) data (Volkens et al. 2017) for party positions and Eurobarometer surveys to measure the ideological polarisation of the electorate. Turnout is used as a proxy for voters' propensity to abstain, and party extremism is measured as the distance between a party's position and the weighted mean of all parties' positions in a given country for each election. The empirical findings provide strong evidence that parties adopt more extreme positions in response to higher voter polarisation and that the size of the effect declines as turnout increases. The effect of voter polarisation on party extremism disappears when turnout is at least 75 per cent.

The findings are robust to the inclusion of various control variables, different model specifications and alternative measures of our dependent variable. For example, we find similar effects when the dependent variable is the commonly used measure of weighted party system dispersion (see Ezrow 2007; Curini and Hino 2012; Matakos et al. 2016; Kosmidis et al. 2018). We also address concerns over potential endogeneity bias, as the direction of causality between turnout and party extremism might run in both directions. While this may be the case for 
individual-level turnout, however, we find no evidence that party positioning affects aggregatelevel turnout. Overall, the robustness checks increase our confidence in the validity of the findings.

This study contributes to the literature on representation by showing that the effect of voter polarisation on party extremism is conditional on voters' propensity to abstain. Parties adopt more extreme positions in response to greater voter polarisation, but only when voters have a high propensity to abstain. The findings build on previous theoretical and empirical studies that either find a positive relationship between voter polarisation and party extremism (Cox 1990, Merrill and Adams 2003; Ezrow 2007) or that argue that no such relationship exists (Dalton 2008). Moreover, our empirical analysis covers an extensive number of elections and ranges from 1977 to 2016, whereas previous studies have relied on much shorter periods of 22 years (Ezrow 2007), fourteen years (Adams et al. 2012b), or two consecutive elections (Dalton

2008). Finally, this study offers a positive outlook for representative democracy. Much of previous scholarship focuses on how abstention fosters unequal representation (Schlozman et al. 2012; Peters and Ensink 2015; Fenzl 2018), while our findings suggest that the threat of abstention can motivate parties to represent a wider range of ideological preferences.

\section{Background and Hypothesis}

Our hypothesis about the conditional effect of voter polarisation builds on previous theoretical and empirical work that argues that parties adopt more extreme positions as the electorate becomes more ideologically polarised. The argument was originally formulated by Downs (1957), who suggested that in multiparty democracies the dispersion of a party system along an ideological left-right dimension would reflect the ideological polarisation of the electorate. Vote-seeking parties adopt more extreme positions when the electorate becomes more 
ideologically polarised, whereas they adopt more moderate positions if voters are compacted together.

Merrill and Adams (2002) later formalised this argument by challenging a standard assumption that voters strictly vote for the ideologically closest party. Instead, voters are assumed to have partisan attachments, which lead voters to bias voting decisions in favour of their 'own' party. For clarity, we refer to voters with such partisan attachments as core constituents and distinguish them from independent swing voters. Numerous empirical studies document the presence of partisan biases, whereby voters perceive their own party as ideologically closer (assimilation bias) and other parties as more ideologically distant (contrast bias) than they actually are (see Campbell et al. 1960; Merrill et al. 2001; Bartels 2002; Drummond 2011). Merrill and Adams (2002) then show that the presence of such partisan attachments in multiparty systems leads increased voter polarisation to shift each party's votemaximising position in the direction of its (non-moderate) core constituents.

The intuition behind such an argument is clear. A party's marginal probability of attracting its own core constituents via policy appeals is higher than the marginal probability of attracting swing voters, who have no attachment to that party. When the electorate becomes more ideologically polarised and voters have more extreme preferences, the share of nonmoderate core constituents will also be higher. This in turn prompts vote-seeking parties to adopt more extreme policy positions. In contrast, a low degree of voter polarisation enables a party to target moderate swing voters without losing support of its core constituents. Building on these arguments, Ezrow (2007) finds that parties adopt more extreme policy positions when voters become more ideologically polarised. Dalton (2008), however, disagrees that voter polarisation should influence party positions on the grounds that parties shift their policy positions for a variety of factors that are unrelated to changes in voter's ideological preferences. 
This study contributes to the debate by arguing that the effect of voter polarisation on party extremism is moderated by voters' propensity to abstain due to alienation.

The propensity to abstain due to alienation refers to the smallest discrepancy between a voter's ideological position and the closest party's position at which that voter will choose to sit out the election (Hinich and Ordeshook 1969). When voters have a high propensity to abstain, they are motivated to vote in an election only if the ideological distance to the closest party is relatively small. In contrast, a low propensity to abstain means that voters are motivated to vote even if the ideological distance to the closest party is relatively large. Previous research reports ample evidence that parties mobilise voters via their policy positions. Lefkofridi et al. (2014), for example, show that voters with extreme ideological preferences become more likely to participate in an election if a party exists that advocates similar positions. In related research, Brockington (2009) finds evidence of a positive correlation between the richness of a system's 'choice environment' and individual-level turnout. Similarly, Wessels and Schmitt (2008) find that voters are more likely to turn out if their ideological preferences are represented (see also Adams et al. 2006). While empirical research shows that a wider ideological range of political offers increases individual-level turnout, there is limited evidence that it also affects aggregatelevel turnout (Ezrow and Xezonakis 2016).

The evidence thus suggests that parties can be effective at mobilising alienated voters, but does abstention due to alienation also motivate parties to shift their policy positions? Merrill and Adams's (2002) theoretical analysis ignores abstention, although the authors discuss its role elsewhere (see Adams and Merrill 2003; Adams et al. 2005). This article addresses the question and posits that the threat of abstention due to alienation is important for understanding the relationship between voter polarisation and party extremism. To understand why this is the case, we simulate scenarios that demonstrate the effect of voter polarisation and abstention based on Merrill and Adams (2002). As the simulated results serve mainly to illustrate the 
mechanism, we provide a detailed description of the theoretical assumptions and the method of calculating parties' vote-maximising positions in the online appendix.

\section{Figure 1: Effects of heightened polarisation on the vote-maximising position}

(a) Low polarisation

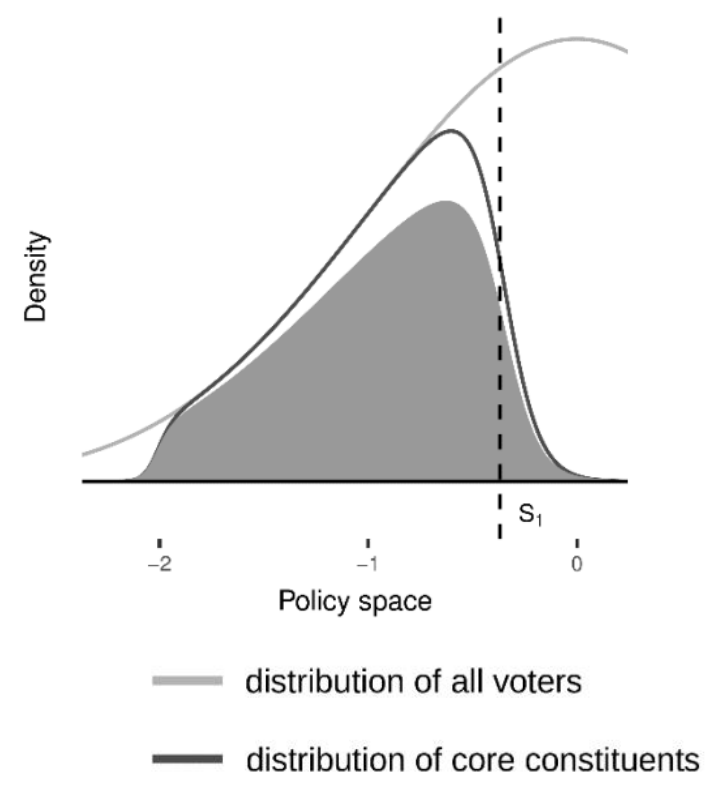

(b) High polarisation

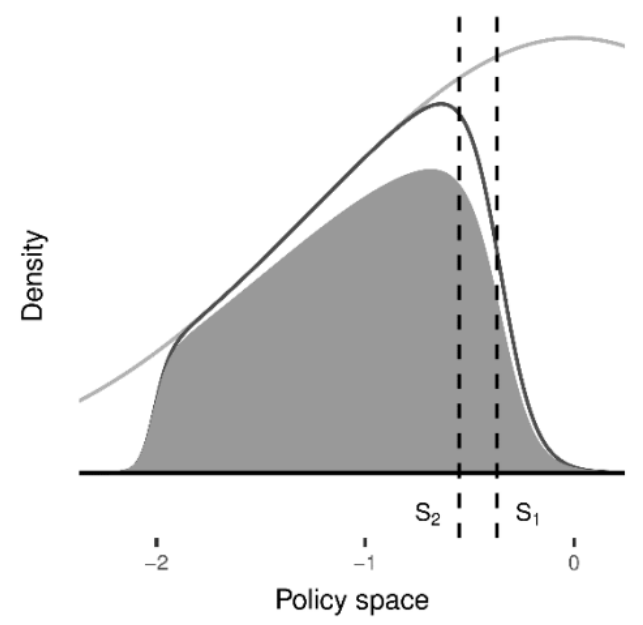

votes from core constituents

Note: Figure 2 (a) shows party l's position $S_{1}$ in the base scenario with low polarisation and low propensity to abstain. Figure 2 (b) shows the party's shift from $S_{1}$ to the new position $S_{2}$ resulting from heightened polarisation. The distribution of voters is indicated by the grey line, the distribution of core constituents of party $l$ by the black line, and the grey area shows the core constituents actually voting for party $l$ out of all its core constituents. The median voter position is at zero.

Figure 1 (a) zooms in on a hypothetical left-wing party $l$ and its core constituents in a multiparty system. ${ }^{1}$ The light grey line represents the distribution of voters along a left-right ideological dimension. Party l's vote-maximising positions $S$ are represented by the vertical dashed line. The dark grey line represents the distribution of the party's core constituents, and the grey area under the curve denotes core constituents who vote for their party. In the first scenario, voters

\footnotetext{
${ }^{1}$ For clarity of presentation, the figure focuses on a party's own core constituents, even though votemaximising positions are based on the entire electorate.
} 
have a low propensity to abstain and polarisation is low. Unsurprisingly, party l's votemaximising position at $S_{1}$ is relatively moderate because core constituents have predominantly moderate preferences.

In the second scenario (figure 1 (b)) the propensity to abstain remains low, but the electorate is more ideologically polarised. Accordingly, core constituents have now spread toward the left extreme of the ideological dimension, causing party l's vote-maximising position also to become more extreme and to shift from $S_{1}$ to $S_{2}$. This result is explained by the fact that core constituents are biased toward their own party, which make marginal policy shifts in the direction of core constituents more effective than marginal policy shifts in the direction of other voters. Although an increase in voter polarisation has shifted party $l$ 's vote-maximising position in the direction of its core constituents, $S_{2}$ is still more moderate than the median core constituent. The reason is that without the threat of abstention, party $l$ faces a low risk of alienating non-moderate core constituents and is thus able to target moderate swing voters with position $S_{2}$. Merrill and Adams (2002) arrive at the same results to those presented in figure 1 . The following scenarios, however, differ in that parties now face a potential threat of abstention. A party's vote-maximising policy position therefore depends not only on whether it maximises the number of voters that prefer that party, but also on whether those voters are willing to participate in the election. 


\section{Figure 2: Effect of heightened propensity to abstain on the vote-maximising position}

(a) Low propensity to abstain

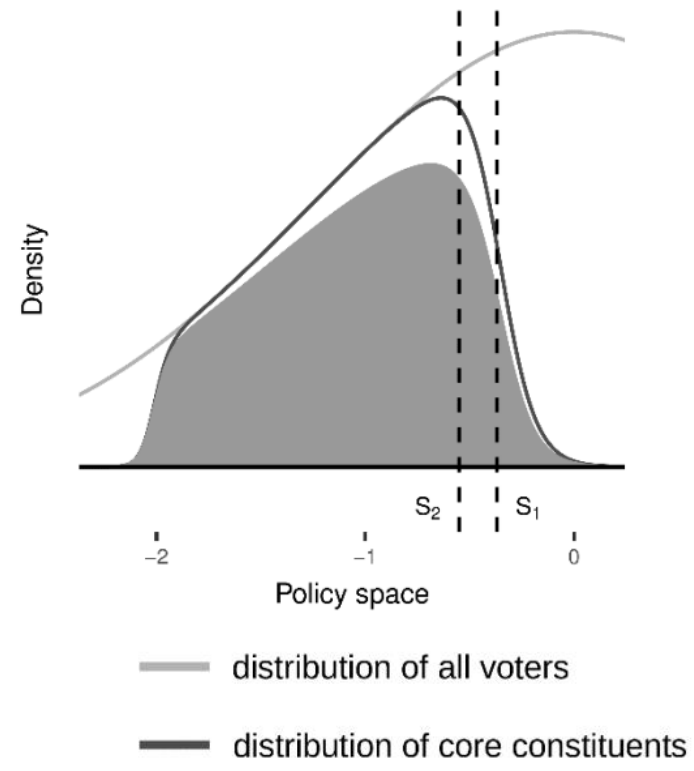

(b) High propensity to abstain

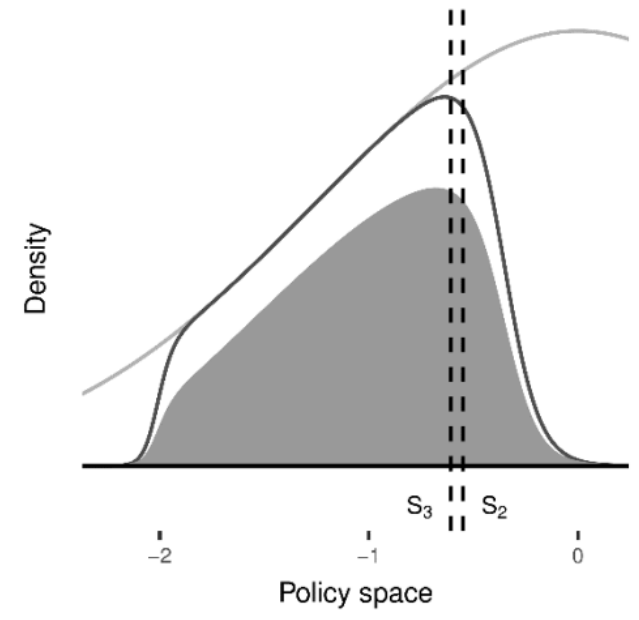

votes from core constituents

Note: Figure (a) shows high polarisation but low propensity to abstain, with party l's original position at $S_{1}$ and the party's position under heightened polarisation at $S_{2}$. Figure (b) shows the party's shift from $S_{2}$ to the new position $S_{3}$ under high polarisation and heightened propensity to abstain.

Figure 2 illustrates how party $l$ 's vote-maximising position changes when voters have a higher propensity to abstain and when the electorate is still ideologically polarised. In scenario (a) the propensity to abstain is low and party l's vote-maximising position is still at $S_{2}$. An increase in voters' propensity to abstain in (b) now shifts party l's vote-maximising position to $S_{3}$. Given voters' increased propensity to abstain, the position $S_{2}$ now alienates a large share of nonmoderate core constituents and no longer maximises party l's vote share. This is because positioning at $S_{2}$ does not yield sufficient votes from moderate swing voters to outweigh vote losses from alienated core constituents. The vote-maximising position therefore becomes more extreme and shifts from $S_{2}$ to $S_{3}$. The threat of abstention among non-moderate core constituents makes moderate party positioning unattractive, and increasingly so as voters spread toward the extremes of the ideological dimension. This leads to the following hypothesis: 
Hypothesis: Higher voter polarisation induces parties to adopt more extreme policy positions, and the effect increases as voters' propensity to abstain increases.

In contrast, lower voter polarisation will motivate parties to adopt more moderate positions, particularly when the threat of moderate voter abstention increases. The reason for this is that extreme party positioning will alienate a larger share of moderate voters if polarisation is low.

While the theoretical reasoning only considers the effect of abstention from alienation, it is important to spell out whether our theoretical predictions would change if abstention was also prompted by indifference. Abstention from indifference occurs if parties are too ideologically similar to justify the cost of voting (Adams et al. 2009). For illustrative purposes we first consider the effects of a party adopting a more radical position. If a party shifts to a radical position in an effort to mobilise its alienated core constituents, the party will simultaneously mobilise moderate indifferent citizens to vote for rival parties (Adams and Merrill 2003). However, by differentiating itself ideologically from other parties, the party will also mobilise its own moderate and indifferent core constituents. Abstention due to indifference should therefore motivate parties to establish a minimum degree of ideological differentiation, but it is not clear to which degree abstention from indifference counteracts the effects of abstention from alienation. The fact that our empirical analysis finds evidence that parties' positions are more radical at higher levels of abstention and polarisation suggests that abstention from indifference does not cancel out the effect of abstention from alienation.

Note also that the effect of voter polarisation depends on the strength of party attachments. Stronger attachments weaken the effect of polarisation because parties have a greater ability to retain the support of their non-moderate core constituents when adopting moderate positions. In support, Ezrow et al. (2014) show that extremist parties benefit less from voter polarisation if party attachments for moderate parties are strong. This means that the risk of moderate parties losing support of their non-moderate core constituents to extremist parties 
depends on the strength of party attachments. Moreover, the threat of extremist parties should be higher in systems that feature a larger number of parties and where party competition is greater. The empirical analysis controls for the effective number of parties in a system, which should incentivise parties to become more extreme (Andrews and Money 2009; Curini and Hino 2012; Matakos et al. 2016). We also follow previous empirical research of party representation by assuming that parties compete for votes by formulating manifestos in which they make public their policy commitments. While policy positions comprise several issue dimensions, for simplicity, we only consider a dominant left-right dimension (see Adams and Somer-Topcu 2009; Adams et al. 2009; Adams and Ezrow 2009; Ezrow et al., 2011; Schumacher et al. 2013).

Because developing party manifestos is time-consuming, parties' policy appeals are retrospective, i.e. they respond to the previous election. Party manifestos usually evolve over several years before an election, during which time party elites, activists, and parties' policy committees have to negotiate and agree on the policies that will be adopted in the party program (Klüver and Spoon 2016; Adams and Somer-Topcu 2009). Policy appeals are retrospective in the sense that parties rely on the previous election to form their expectations about voters' behaviour in the current election. For example, high abstention in the previous election serves as a proxy for voters' propensity to abstain in the following election. Similarly, voter polarisation in the previous election serves as a guide for polarisation in the current election. The focus on these lagged measures is also justified because alternative predictions of abstention and polarisation are less informative. Surveys and polls tend to overestimate turnout because non-voters are under-sampled and respondents often misreport voting intentions (Mellon and Prosser 2017). Moreover, voter turnout from regional elections cannot accurately predict abstention at national elections because they tend to be less salient. 


\section{Empirical Operationalisation}

Our hypothesis posits that parties adopt more extreme positions in response to higher voter polarisation in the previous election, and that the effect is conditional on voters' propensity to abstain. Accordingly, parties are expected to respond more strongly to voter polarisation as voters' propensity to abstain in the previous election increases. To test the conditional effect of polarisation on party positioning, we require longitudinal and cross-national measures of party extremism, voter polarisation and voters' propensity to abstain.

We rely on Comparative Manifesto Project (CMP) (Volkens et al. 2017) data to measure party extremism on a dominant left-right policy dimension. The CMP has coded party programs of most significant parties since 1945 in over 50 countries and therefore provides a useful longitudinal and cross-sectional measure of parties' policy positions that is widely used in research on party representation (see Adams et al. 2004; Ezrow 2007; Jansen et al. 2013; Adams et al. 2014; Adams et al. 2016). Using parties' election manifestos, the CMP identifies what proportion of quasi-sentences can be allocated to each of the 54 policy areas that are identified. Left-right scores are then measured as the difference in percentages of right statements from the percentages of left statements, divided by the total number of statements. The definition of left and right statements was developed by Laver and Budge (1992) who use within-country factor analysis of a range of coding categories that load consistently at the opposite ends of the underlying dimension.

The CMP left-right measure has been found to be consistent with those utilised by other party positioning studies, such as expert placements, voters' perceptions of party positions or parliamentary voting of party members, which strengthens our confidence in the reliability of the CMP measure (Hearl 2001; Laver et al. 2003; McDonald and Mendes 2001).

Party positions range from -100 to +100 , whereby higher values denote more rightwing positions. We have rescaled party positions from the -100 to +100 scale used by the CMP 
to fit the 1-10 scale that is used by Eurobarometer surveys. By using the same scale for party positions and voters' ideological preferences, we are able to draw meaningful comparisons between the degree of party extremism and voters' ideological dispersion. Our measure for party extremism is based on the distance between a party and the weighted mean of all parties' left-right positions in a given country for each election year. The more distant a party is from the weighted mean of all parties' left-right positions, the more extreme that party is thought to be (see Alvarez and Nagler 2004; Ezrow 2007; Dalton 2008; Curini and Hino 2012). Our measure of party extremism is defined as:

$$
\text { Party Extremism }=\sqrt{\left(P_{j k}-\bar{P}_{k}\right)^{2}}
$$

where $P$ denotes the left-right position of party $j$ in country $k$ and $\bar{P}_{k}$ is the weighted mean leftright position of all parties in country $k$ for a given election year. Party extremism ranges from 0 to 9 , whereby higher values denote a greater distance between a party's left-right position and the mean left-right position of all parties. The unit of analysis in this study is hence the political party. While our measure of party extremism focuses on the positioning of individual parties, recent studies that seek to explain party positioning have predominantly employed a measure of party system dispersion that is weighted by party size (Ezrow 2007; Dalton 2008; Curini and Hino 2012; Matakos et al. 2016; Kosmidis et al. 2018). We therefore test whether our findings are robust to using a weighted measure of party system dispersion, which is defined as:

$$
\text { Weighted Party System Dispersion }=\sqrt{\sum_{j=1} V S_{j}\left(P_{j k}-\bar{P}_{k}\right)^{2}}
$$

Data on voters' ideological preferences is based on Eurobarometer surveys. Eurobarometer surveys ask approximately 1,000 respondents from each country each year on where they would place themselves on a left-right ideological scale from 1 to 10 , where higher values indicate more right-wing preferences. The first year in our dataset is 1976, which is when the Eurobarometer surveys began to ask voters to place themselves on a left-right ideological scale 
on a yearly basis. The dataset covers the following eleven Western European democracies: Denmark, France, Germany, the United Kingdom, Greece, Ireland, Italy, Luxembourg, Netherlands, Portugal, and Spain. Belgium is not included in the dataset because it features a compulsory voting system with high turnout levels that exhibit little variation over time. Our measure of voters' ideological polarisation is based on the standard deviation of respondents' ideological preferences in the Eurobarometer surveys (see Alvarez and Nagler 2004; Ezrow 2007; Dalton 2008; Adams et al. 2012b; Ezrow et al. 2014). A greater standard deviation means that the share of voters who have more extreme ideological preferences is higher. Data on voter turnout comes from the International Institute for Democracy and Electoral Assistance (2017). As discussed in the theoretical analysis, given polarisation, turnout from the previous election is used as a proxy for voters' propensity to abstain in the current election.

Previous studies of representation suggest that policy positions of parties depend on the incentives created by electoral laws. Matakos et al. (2016), for example, argue that party extremism decreases with electoral disproportionality and increases with the effective number of parties (see also Cox 1997; Andrews and Money 2009; Dow 2011; Curini and Hino 2012). In contrast, Ezrow (2008) finds no evidence that more proportional systems or a higher number of effective parties promote extreme party positioning. We control for potential effects of electoral laws by including variables for electoral disproportionality and the effective number of parties. Electoral system disproportionality scores are based on Gallagher (1991) and the effective number of parties on the votes level is based on the measure developed by Laakso and Taagepera (1979). We rely on the Comparative Political Data Set for data on both variables (Armingeon et al. 2017).

In related research, Ezrow (2007) argues that parties are more responsive to changes in the polarisation of voters' ideological preferences in less proportional voting systems, which motivate parties to emphasise vote-seeking objectives. In the online appendix, we therefore test 
whether parties respond more strongly to voter polarisation and turnout in less proportional systems. Consistent with Ezrow (2007), we find some evidence that electoral disproportionality magnifies the conditional effect of voters' ideological polarisation on party extremism.

Finally, the empirical analysis controls for whether a party held the prime minister position at the time of the election. Our expectation is that the prime minister's party tends to follow a broader representation strategy and therefore adopts more centrist policy positions than other parties. Data on the prime ministerial status of a party is taken from the Parlgov database (Döring and Manow 2016). The Parlgov database also provides information on vote shares, which is used for our measure of weighted party system dispersion.

\section{Model Specification and Findings}

To test our hypothesis, we estimate two types of statistical models. The first type is a timeseries cross-sectional model with country or party fixed effects. It is specified as follows:

$$
E_{i t}=\propto+\beta_{1} W_{i t-1}+\gamma X_{i t-1}+\delta_{i}+\sigma_{t}+\varepsilon_{i t}
$$

where $E_{i t}$ is a party's degree of left-right policy extremism in country $i$ at election year $t ; \propto$ is a constant; $W$ is a vector of the independent variables and an interaction between turnout and voter polarisation; $X$ is a vector of control variables, which include electoral disproportionality, the effective number of parties, and prime minister party status; $\delta$ are country or party fixed effects; $\sigma$ are decade fixed effects; $\beta$ and $\gamma$ are the parameters to be estimated; $\varepsilon$ is the error term. This type of model controls for unobserved and time-invariant party- or country-specific fixed effects as well as decade fixed effects.

The second type is a pooled time-series cross-sectional model without fixed effects but with a lagged dependent variable, and it is specified as:

$$
E_{i t}=\propto+\rho_{1} E_{i t-1}+\beta_{1} W_{i t-1}+\gamma X_{i t-1}+\varepsilon_{i t}
$$


The key assumption of the second type of model is that the most important omitted variables that explain party extremism are not time-invariant, but that party extremism in the current election is predicted by party extremism in the previous election. Including a lagged dependent variable in the model deals with the issue of autocorrelation but prevents us from also including fixed effects, as estimates would be biased and inconsistent (Nickell 1981). Angrist and Pischke's (2009) advice is therefore to compare estimates from the fixed effects model and the model with a lagged dependent variable because the true causal effect is likely to be bracketed by both types of models. The empirical analysis reveals that estimates from both types of models are similar, which suggests that our findings are robust to different identifying assumptions. Moreover, we follow the suggestion of Plümper et al. (2005) to use a PraisWinsten transformation rather than a lagged dependent variable to eliminate serial correlation of the error term. The authors suggest that the inclusion of a lagged dependent variable can be problematic in panel data analyses because it absorbs much of the theoretically interesting timeseries variance. Results from the models using a Prais-Winsten transformation are reported in the online appendix and they are consistent with estimates from the fixed effects models and models that include a lagged dependent variable.

The empirical analysis evaluates the effect of lower levels of abstention and polarisation in the previous election on the diversity of party positions in the current election. Although modelling changes in the independent variables would be an interesting alternative, such an approach presents at least two difficulties. First, a simple model based on changes does not account for cumulative effects. However, it is likely that parties adjust their positions only once turnout has decreased to a sufficiently low level. Indeed, a simple translation of our specified model to consider changes in the key variables does not find a statistically significant effect of a change in turnout and polarisation (see table 7 in the online appendix). Second, modelling changes in the independent variables would ignore that the interaction effect between turnout 
and polarisation depends on countries' average levels of turnout and polarisation. We find evidence that the same change in turnout will have a smaller effect in a country with higher turnout (see table 6 in the online appendix). Similarly, we expect that parties will respond more strongly to an increase in polarisation in countries with lower average polarisation. It is therefore more appropriate to evaluate our hypothesis by modelling the effect of polarisation and turnout on party positions.

Five different models are estimated. The first model includes the main independent variables and the interaction as well as country- and decade-specific fixed effects. The second model includes a lagged dependent variable instead of fixed effects. We add control variables to all remaining models and observe how estimates change when party-specific fixed effects are included instead of country-specific fixed effects, or when a lagged dependent variable is included instead of fixed effects. All models that include a lagged dependent variable are estimated with panel-corrected standard errors to deal with panel heteroscedasticity (Beck and Katz 1995). Because the dataset is unbalanced, the interpanel covariance matrix of the disturbances is estimated using pairwise selection.

The fixed effects models are based on 695 observations of 154 parties from eleven Western European countries between 1977 and 2016. Because in our model parties respond to voter polarisation and turnout in the previous election, one observation is sacrificed for each party that contested an election in the first year covered in our dataset. The models that include a lagged dependent variable are based on 600 observations from 119 parties, as one observation is sacrificed for each party that appears in only one election year (35 parties) or that came into existence after the first election year covered in the dataset for a given country (60 parties). 
Table 1: Party extremism in eleven Western European countries, 1977-2016

\begin{tabular}{|c|c|c|c|c|c|}
\hline & Model 1 & Model 2 & Model 3 & Model 4 & Model 5 \\
\hline Party extremism $\mathrm{t}-1$ & & $\begin{array}{l}0.494 * * * \\
(0.074)\end{array}$ & & & $\begin{array}{l}0.457 * * * \\
(0.074)\end{array}$ \\
\hline Turnout $\mathrm{t}-1$ & $\begin{array}{l}0.103 * * \\
(0.043)\end{array}$ & $\begin{array}{l}0.084 * * \\
(0.034)\end{array}$ & $\begin{array}{l}0.094 * \\
(0.043)\end{array}$ & $\begin{array}{l}0.070 * * \\
(0.032)\end{array}$ & $\begin{array}{l}0.081 * * \\
(0.032)\end{array}$ \\
\hline Polarisation $\mathrm{t}-1$ & $\begin{array}{l}4.775 * * \\
(1.958)\end{array}$ & $\begin{array}{l}3.130 * * \\
(1.252)\end{array}$ & $\begin{array}{l}4.317 * * \\
(1.809)\end{array}$ & $\begin{array}{l}3.295 * * * \\
(1.258)\end{array}$ & $\begin{array}{l}2.969 * * \\
(1.227)\end{array}$ \\
\hline Disproportionality $\mathrm{t}-1$ & & & $\begin{array}{l}0.004 \\
(0.016)\end{array}$ & $\begin{array}{l}-0.002 \\
(0.010)\end{array}$ & $\begin{array}{l}0.007 \\
(0.006)\end{array}$ \\
\hline PM party $\mathrm{t}-1$ & & & $\begin{array}{l}-0.225^{* * *} \\
(0.055)\end{array}$ & $\begin{array}{l}-0.072 \\
(0.061)\end{array}$ & $\begin{array}{l}-0.124 * * * \\
(0.044)\end{array}$ \\
\hline $\begin{array}{l}\text { Effective number of } \\
\text { parties t-1 }\end{array}$ & & & $\begin{array}{l}0.032 \\
(0.019)\end{array}$ & $\begin{array}{l}0.023 \\
(0.029)\end{array}$ & $\begin{array}{l}0.052 * * \\
(0.021)\end{array}$ \\
\hline Polarisation $\mathrm{t}-1 \mathrm{x}$ Turnout $\mathrm{t}-1$ & $\begin{array}{l}-0.057 * * \\
(0.023)\end{array}$ & $\begin{array}{l}-0.039 * * \\
(0.017)\end{array}$ & $\begin{array}{l}-0.052 * * \\
(0.022)\end{array}$ & $\begin{array}{l}-0.040 * * \\
(0.016)\end{array}$ & $\begin{array}{l}-0.037 * * \\
(0.016)\end{array}$ \\
\hline Constant & $\begin{array}{l}-7.698 * * \\
(3.620)\end{array}$ & $\begin{array}{l}-6.414 * * \\
(2.509)\end{array}$ & $\begin{array}{l}-7.112^{*} \\
(3.539)\end{array}$ & $\begin{array}{l}-4.838^{*} \\
(2.527)\end{array}$ & $\begin{array}{l}-6.379 * * * \\
(2.456)\end{array}$ \\
\hline Lagged dependent variable & & Yes & & & Yes \\
\hline Country fixed effects & Yes & & Yes & Yes & \\
\hline Party fixed effects & & & & Yes & \\
\hline Decade fixed effects & Yes & & Yes & & \\
\hline R-squared: within & 0.036 & & 0.064 & 0.060 & \\
\hline R-squared: between & 0.000 & & 0.082 & 0.010 & \\
\hline R-squared: overall & 0.004 & 0.289 & 0.051 & 0.036 & 0.312 \\
\hline Observations & 695 & 600 & 695 & 695 & 600 \\
\hline
\end{tabular}

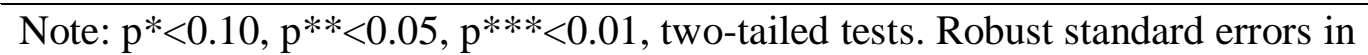
parentheses. Panel-corrected standard errors in models 2 and 5.

Results from the five regression models are presented in table 1. In all models the interaction between voter polarisation and turnout is negative and statistically significant, indicating that the effect of voter polarisation on party extremism declines as turnout increases. Voter polarisation is found to have a positive and statistically significant effect on party extremism. Accordingly, parties adopt more extreme positions when polarisation was high in the previous election, but higher turnout in the previous election weakens parties' response to voter polarisation. These findings give support to our main hypothesis, which suggests that parties adopt more extreme positions in response to higher voter polarisation and that this effect is 
conditioned by voters' propensity to abstain. The interaction effect remains statistically significant when controls are added in the third, fourth, and fifth models. The size of the coefficient, however, becomes smaller. For example, the coefficient for the interaction in the first model, which includes country fixed effects, changes from -0.057 to -0.052 when controls are added in the third model. The size of the coefficient changes to -0.040 when party fixed effects are used instead of country fixed effects. An explanation for why the interaction effect becomes weaker in model 4 is that unit fixed effects (i.e. party) eliminate much of the crosssectional variance by focusing instead on variation within units.

\section{Figure 3: Marginal effects of polarisation on party extremism}
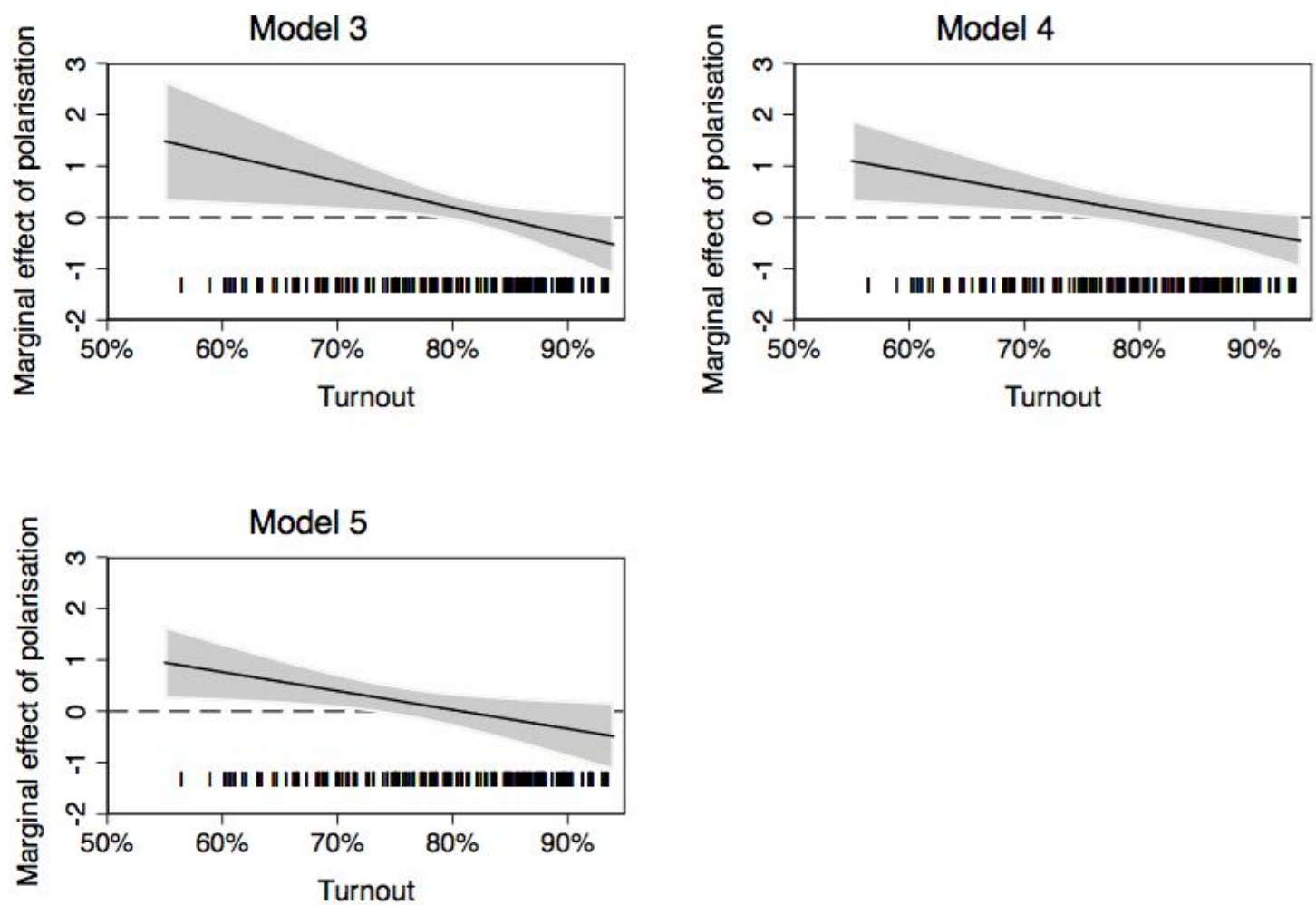

Note: Fitted values are presented with ninety-five per cent confidence intervals. Positions of the data points along the $\mathrm{x}$-axis are represented by tick marks. 
The results from model 5, which includes a lagged dependent variable, are similar to the alternative models. The coefficient of the interaction effect is -0.037 and is thus the smallest estimate compared to the previous models. To facilitate interpretation of the interaction effect, figure 3 shows marginal effects of voter polarisation on party extremism for different levels of turnout. The figures clearly demonstrate that the effect of voter polarisation on party extremism is positive when turnout was low in the previous election and that the effect of voter polarisation decreases as turnout increases. Voter polarisation has no effect on party extremism at higher levels of turnout. According to the estimates from our different models, the effect of voter polarisation is no longer statistically significant when turnout in the previous election is between 75 and 80 per cent.

Consistent with our expectations, we find some evidence that parties adopt more moderate positions when they were the party of the prime minister at the time of the election. Similar to Ezrow (2008), we find not much evidence that electoral disproportionality or the effective number of parties affect party extremism. In model 5, however, an increase in the effective number of parties induces parties to adopt more extreme positions, which is consistent with findings from previous studies (see Andrews and Money 2009; Curini and Hino 2012). Overall, our findings provide strong support for our argument that voter polarisation leads parties to adopt more extreme positions and that the effect is moderated by voter turnout.

The empirical findings are robust to different identifying assumptions, as the estimates from the fixed effects models and the ones from models that include a lagged dependent variable are similar. As a further check, we show in table 2 that our estimates of the interaction effect between voter polarisation and turnout are robust when our dependent variable is weighted party system dispersion. The findings provide additional support for our hypothesis and show that different measurements of the dependent variable and different model specifications lead to the same conclusions. Another expectation is that the findings are 
stronger in countries with lower average turnout because these countries exhibit greater variation in turnout. Indeed, we find some evidence that the interaction effect between turnout and polarisation is stronger in countries with lower average turnout, but the difference between low and high turnout countries is small (see table 6 in the online appendix).

Table 2: Party system dispersion in eleven Western European countries, 1977-2016

\begin{tabular}{|c|c|c|c|c|}
\hline & Model 1 & Model 2 & Model 3 & Model 4 \\
\hline Party extremism $\mathrm{t}-1$ & & $\begin{array}{l}0.443 * * * \\
(0.098)\end{array}$ & & $\begin{array}{l}0.457 * * * \\
(0.074)\end{array}$ \\
\hline Turnout $\mathrm{t}-1$ & $\begin{array}{l}0.087 * * \\
(0.039)\end{array}$ & $\begin{array}{l}0.076^{* *} \\
(0.037)\end{array}$ & $\begin{array}{l}0.081 * * \\
(0.039)\end{array}$ & $\begin{array}{l}0.082 * * \\
(0.037)\end{array}$ \\
\hline Polarisation $\mathrm{t}-1$ & $\begin{array}{l}3.658 * * \\
(1.152)\end{array}$ & $\begin{array}{l}2.749 * \\
(1.436)\end{array}$ & $\begin{array}{l}3.373^{* *} \\
(1.520)\end{array}$ & $\begin{array}{l}2.879 * * \\
(1.421)\end{array}$ \\
\hline Disproportionality t-1 & & & $\begin{array}{l}-0.008 \\
(0.012)\end{array}$ & $\begin{array}{l}0.008 \\
(0.006)\end{array}$ \\
\hline $\begin{array}{l}\text { Effective number of } \\
\text { parties t-1 }\end{array}$ & & & $\begin{array}{l}0.071^{*} \\
(0.037)\end{array}$ & $\begin{array}{l}0.039 \\
(0.026)\end{array}$ \\
\hline Polarisation $\mathrm{t}-1 \mathrm{x}$ Turnout $\mathrm{t}-1$ & $\begin{array}{l}-0.045^{* *} \\
(0.019)\end{array}$ & $\begin{array}{l}-0.034^{*} \\
(0.018)\end{array}$ & $\begin{array}{l}-0.040 * * \\
(0.019)\end{array}$ & $\begin{array}{l}-0.036^{* *} \\
(0.018)\end{array}$ \\
\hline Constant & $\begin{array}{l}-6.401 * * \\
(3.113)\end{array}$ & $\begin{array}{l}-5.723 * * \\
(2.912)\end{array}$ & $\begin{array}{l}-6.186^{* *} \\
(3.085)\end{array}$ & $\begin{array}{l}-6.315^{* *} \\
(2.874)\end{array}$ \\
\hline Lagged dependent variable & & Yes & & \\
\hline Country fixed effects & Yes & & Yes & Yes \\
\hline Decade fixed effects & Yes & & Yes & \\
\hline R-squared: within & 0.165 & & 0.201 & \\
\hline R-squared: between & 0.024 & & 0.200 & \\
\hline R-squared: overall & 0.097 & 0.356 & 0.215 & 0.383 \\
\hline Observations & 102 & 102 & 102 & 102 \\
\hline
\end{tabular}

While the marginal effects plots in figure 3 clarify the conditions under which the predicted effects are statistically significant, it is important to also address the substantive significance of these estimated effects. We consider the marginal effect of a typical increase in voter polarisation on parties' predicted positions at different levels of turnout. In our dataset the mean and median change in voter polarisation between two consecutive elections is 0.10 . When voter turnout is 60 percent, the marginal effect of a 0.10 increase in voter polarisation is associated 
with an increase in party extremism of at least 0.12 , which represents a seven percent increase relative to the entire range of the party extremism variable. In contrast, when voter turnout is 70 percent, the marginal effect of a 0.10 increase in voter polarisation on party extremism is 0.07, which represents a four percent increase. The marginal effect of voter polarisation on party extremism is therefore almost halved by a ten percent increase in voter turnout. As turnout reaches 80 percent, higher voter polarisation is no longer associated with more extreme policy positions.

We can illustrate the substantive significance of our findings further by looking at a concrete example from the Netherlands. The ideological polarisation of the Dutch electorate increased by the same amount before the 2003 and 2012 elections, but voter turnout differed across both elections. In 2010 turnout was 75 percent, which is four percent below the national average in our dataset, and an increase in voter polarisation of 0.10 led to a 17 percent increase in party system dispersion in the following election. All parties except for the Christian Union adopted a more radical policy position compared to the previous election. In 2002 turnout was 79 percent, which is the mean turnout in our dataset, and an increase in voter polarisation by approximately 0.1 led to an increase in party extremism of only six percent in the following election. While the VVD and CDA adopted more radical positions, other parties either adopted more moderate positions or did not change their positions. The example demonstrates that voter polarisation can have substantial effects on parties' ideological positions, particularly at lower levels of voter turnout.

The empirical analysis has shown that parties adopt more extreme positions in response to higher voter polarisation, and that the effect is moderated by turnout. The finding is explained by our theoretical argument that parties have more to gain from responding to voter polarisation when voters have a higher propensity to abstain, as adopting more extreme positions helps to mobilise core constituents. While voters' propensity to abstain is exogenous 
in our theoretical analysis, voter turnout may be endogenous to party system dispersion. If voter turnout is endogenous to party system dispersion, our model estimates will be biased. We therefore test whether party system dispersion in the previous election influences turnout in the current election.

Evidence from previous studies on the relationship between party system dispersion and turnout is mixed. Steiner and Martin (2012), for example, find that party polarisation has a negative effect on turnout, even though the effect is small. In related work, Ezrow and Xezonakis (2016) find no evidence that party polarisation affects turnout (see also Cancela and Geys 2016). We test for the potential endogeneity of turnout by regressing turnout in the current election on party system dispersion in the previous election. The results are reported in table 2 in the online appendix, and they show that party system dispersion does not lead to higher turnout.

We therefore conclude that estimates of the interaction effect between turnout and voter polarisation in table 1 are unlikely to be biased, as we find no evidence that turnout is endogenous to party system dispersion. Although parties can affect individual turnout decisions in our theoretical analysis, aggregate turnout appears to depend more strongly on factors unrelated to party system dispersion. This finding is consistent with previous empirical research that shows a strong positive correlation between party system dispersion and voters' likelihood to turn out (see Wessels and Schmitt 2008; Brockington 2009; Lefkofridi et al. 2014), while there is less evidence that party system dispersion also affects aggregate turnout (Ezrow and Xozonakis 2016). The fact that aggregate turnout is exogenous to party system dispersion thus does not mean that parties' policy positioning is ineffective at mobilising core constituents. 


\section{Discussion and Conclusion}

This article has emphasised the importance of abstention for understanding when parties' policy positions respond to the ideological polarisation of voters. We have argued that parties face incentives to respond to voter polarisation by adopting more extreme policy positions, and that these incentives become stronger when voters have a higher propensity to abstain. If the electorate is highly polarised, parties risk alienating their non-moderate core constituents when adopting moderate policy positions. This risk is magnified if voters have a higher propensity to abstain, as in this case moderate party positioning will alienate a larger share of nonmoderate core constituents. An empirical analysis of party positions between 1977 and 2016 in eleven Western European democracies strongly supports this argument. We find that parties adopt more extreme positions when voter polarisation was higher in the previous election, but the effect declines as turnout increases. The effect of voter polarisation disappears when turnout is at least 75 per cent.

Previous theoretical work has predicted that parties become more extreme when the electorate is more ideologically polarised (see Downs 1957; Cox 1990, Merrill and Adams 2002), but recent empirical findings present conflicting evidence. While Ezrow (2007) finds support for the voter polarisation effect, other empirical studies report that no such relationship exists (Dalton 2008; Adams et al. 2012b). By emphasising the importance of abstention, we have shown that voter polarisation should induce parties to become more extreme only when the threat of abstention is large. Adams et al. (2012b), for example, find that the British Labour and Conservative Parties become more moderate between 1987 and 2001 even though the electorate did not depolarise during that time. Consistent with our arguments, we note that turnout in the UK was relatively high until it dropped below sixty percent in 2001, which prompted both parties to adopt more extreme positions in the following election. Higher abstention thus increases the effect of voter polarisation on parties' policy positions. 
Our findings should be of interest to the study of representation and party competition. While much attention has been given to factors that explain median voter representation (see Powell 2009; Adams et al. 2004; McDonald and Budge 2005; Adams et al. 2009; Ward et al. 2011; Schumacher et al. 2013), we focus instead on whether parties adopt more extreme positions when voters are more ideologically polarised. Some scholars have raised concerns that increased party extremism decreases satisfaction with democracy (Ezrow and Xezonakis 2011) or that it reduces voters' reliance on substantive information to guide their policy opinions (Druckman et al. 2013). Nevertheless, we suggest that our findings offer a positive outlook to representative democracy, as party systems should represent not only the preferences of the median voter but also the diversity of voter preferences (Pitkin 1967, Cox 1997, Ezrow 2007; Andrews and Money 2009). When parties present non-moderate policy positions, voters have more meaningful choices. This leads to stronger party attachments, more ideologically consistent voting, and greater electoral stability (Lachat 2008; Lupu 2015; Jansen et al. 2013). This article also contributes to the study of representation by showing that the threat of abstention can motivate parties to represent a wider range of policy options. Although previous research has acknowledged the ability of parties to mobilise voters via policy appeals, the predominant view is still that low turnout among working class individuals fosters unequal representation (see Lijphart 1997; Schlozman et al. 2012; Peters and Ensink 2015; Fenzl 2018). We challenge this view and suggest that abstention from alienation induces parties to improve representation of their core constituents.

The findings raise interesting questions for future research. While this article has demonstrated that higher voter abstention makes parties more responsive to voter polarisation, future research should investigate the effect of party polarisation on individual level turnout. Our analysis presupposes that parties adopt more radical positions to mobilise their alienated non-moderate core constituents, and it would be interesting to examine whether voters respond 
to parties' policy strategies. Moreover, this study only considers the effects of polarisation and abstention on party extremism on a dominant left-right policy dimension. Future research should therefore explore the robustness of our empirical findings when considering additional issue dimensions. Future research should also extend the scope of this study beyond Western European countries and consider multiparty democracies in Eastern Europe and across the world. Nevertheless, this study marks an important step forward in the understanding of party representation in multiparty democracies and the influence of voter polarisation and abstention. 


\section{References}

Adams, James, Michael Clark, Lawrence Ezrow, and Garrett Glasgow (2004). 'Understanding Change and Stability in Party Ideologies: Do Parties Respond to Public Opinion or to Past Election Results?', British Journal of Political Science, 34:04, 589-610.

Adams, James, Catherine De Vries, and Debra Leiter (2012a). 'Subconstituency Reactions to Elite Depolarization in the Netherlands: An Analysis of the Dutch Public's Policy Beliefs and Partisan Loyalties, 1986-98', British Journal of Political Science, 42:01, 81-105.

Adams, James, Jay Dow, and Samuel Merill (2006). 'The political consequences of alienationbased and indifference-based voter abstention: Applications to Presidential Elections', Political Behavior, 28:1, 65-86.

Adams, James, Lawrence Ezrow, and Zeynep Somer-Topcu (2014). 'Do Voters Respond to Party Manifestos or to a Wider Information Environment? An Analysis of Mass-Elite Linkages on European Integration', American Journal of Political Science, 58:4, 967-978.

Adams, James, Lawrence Ezrow, and Christopher Wlezien (2016). 'The Company You Keep: How Voters Infer Party Positions on European Integration from Governing Coalition Arrangements', American Journal of Political Science, 60:4, 811-823.

Adams, James F., Samuel Merrill, and Bernard Grofman (2005). A unified theory of party competition: a cross-national analysis integrating spatial and behavioral factors. Cambridge: Cambridge University Press.

Adams, James, Jane Green, and Caitlin Milazzo (2012b). 'Has the British Public Depolarized Along With Political Elites? An American Perspective on British Public Opinion', Comparative Political Studies, 45:4, 507-530.

Adams, James, Andrea Haupt, and Heather Stoll (2009). 'What Moves Parties? The Role of Public Opinion and Global Economic Conditions in Western Europe', Comparative Political Studies, 42:5, 611-639.

Adams, James, and Samuel Merrill (2003). 'Voter Turnout and Candidate Strategies in American Elections', Journal of Politics, 65:1, 161-189.

Adams, James, and Zeynep Somer-Topcu (2009). 'Policy Adjustment by Parties in Response to Rival Parties' Policy Shifts: Spatial Theory and the Dynamics of Party Competition in Twenty-Five Post-War Democracies', British Journal of Political Science, 39:04, 825-846. 
Alvarez, R. Michael, and Jonathan Nagler (2004). 'Party System Compactness: Measurement and Consequences', Political Analysis, 12:1, 46-62.

Andrews, Josephine, and Jeannette Money (2009). 'The Spatial Structure of Party Competition: Party Dispersion within a Finite Policy Space', British Journal of Political Science, 39:04, 805-824.

Angrist, Joshua D., and Jörn-Steffen Pischke (2008). Mostly harmless econometrics: An empiricist's companion. Princeton, NJ: Princeton University Press.

Armingeon, Klaus, and Lisa Schädel (2015). 'Social Inequality in Political Participation: The Dark Sides of Individualisation', West European Politics, 38:1, 1-27.

Bartels, Larry M. (2002). 'Beyond the Running Tally: Partisan Bias in Political Perceptions', Political Behavior, 24:2, 117-150.

Beck, Nathaniel, and Jonathan N. Katz (1995). 'What to do (and not to do) with time-series crosssection data', American political science review, 89:3, 634-647.

Benoit, Kenneth, and Michael Laver (2009). Party policy in modern democracies. London: Routledge.

Bischof, Daniel (2017). 'New Graphic Schemes for Stata: Plotplain and Plottig', The Stata Journal: Promoting communications on statistics and Stata, 17:3, 748-759.

Brockington, David (2009). 'It's About the Benefits: Choice Environments, Ideological Proximity and Individual Participation in 28 Democracies', Party Politics, 15:4, 435-454.

Campbell, Angus, Philip Converse, Warren Miller, and Donald Stokes (1960). The American Voter. Chicago, IL: University of Chicago Press.

Cancela, João, and Benny Geys (2016). 'Explaining voter turnout: A meta-analysis of national and subnational elections', Electoral Studies, 42, 264-275.

Cox, Gary W. (1990). 'Centripetal and centrifugal incentives in electoral systems', American Journal of Political Science, 34:4, 903-935.

Cox, Gary W. (1997). Making votes count: strategic coordination in the world's electoral systems. Cambridge: Cambridge University Press.

Curini, Luigi, and Airo Hino (2012). 'Missing Links in Party-System Polarization: How Institutions and Voters Matter', The Journal of Politics, 74:2, 460-473.

Dalton, Russell J. (2008). 'The Quantity and the Quality of Party Systems: Party System Polarization, Its Measurement, and Its Consequences', Comparative Political Studies, 41:7, 899-920. 
Döring, Herbert, and Philipp Manow (2016). Parliaments and governments database (ParlGov): Information on parties, elections and cabinets in modern democracies. Development version [Dataset]. Retrieved from http://www.parlgov.org/ (accessed 14 March 2018).

Dow, Jay K. (2011). 'Party-System Extremism in Majoritarian and Proportional Electoral Systems', British Journal of Political Science, 41:2, 341-361.

Downs, Anthony (1957). An economic theory of democracy. New York: Harper \& Row.

Druckman, James N., Erik Peterson, and Rune Slothuus (2013). 'How Elite Partisan Polarization Affects Public Opinion Formation', American Political Science Review, 107:1, 57-79.

Drummond, Andrew (2010). 'Assimilation, contrast and voter projections of parties in left-right space: Does the electoral system matter?', Party Politics, 17:6, 711-743.

Ezrow, Lawrence (2005). 'Are moderate parties rewarded in multiparty systems? A pooled analysis of Western European elections, 1984-1998', European Journal of Political Research, 44:6, 881-898.

Ezrow, Lawrence (2007). 'The Variance Matters: How Party Systems Represent the Preferences of Voters', Journal of Politics, 69:1, 182-192.

Ezrow, Lawrence (2008). 'Parties' Policy Programmes and the Dog That Didn't Bark: No Evidence That Proportional Systems Promote Extreme Party Positioning', British Journal of Political Science, 38:3, 479-497.

Ezrow, Lawrence, Margit Tavits, and Jonathan Homola (2014). 'Voter Polarization, Strength of Partisanship, and Support for Extremist Parties', Comparative Political Studies, 47:11, $1558-1583$.

Ezrow, Lawrence, Catherine De Vries, Marco Steenbergen, and Erica Edwards (2011). 'Mean voter representation and partisan constituency representation: Do parties respond to the mean voter position or to their supporters?', Party Politics, 17:3, 275-301.

Ezrow, Lawrence, and Georgios Xezonakis (2011). 'Citizen Satisfaction with Democracy and Parties' Policy Offerings', Comparative Political Studies, 44:9, 1152-1178.

Ezrow, Lawrence, and Georgios Xezonakis (2016). 'Satisfaction with democracy and voter turnout: A temporal perspective', Party Politics 22:1, 3-14.

Fenzl, Michele (2018). 'Income inequality and party (de)polarisation', West European Politics, 120.

Gallagher, Michael (1991). 'Proportionality, disproportionality and electoral systems', Electoral Studies, 10:1, 33-51. 
Hinich, Melvin J., and Peter C. Ordeshook (1969). 'Abstentions and equilibrium in the electoral process', Public Choice, 7:1, 81-106.

International Institute for Democracy and Electoral Assistance. (2017). Voter Turnout Database [Dataset]. Retrieved from https://www.idea.int/data-tools/data/voter-turnout (accessed 14 March 2018).

Jansen, Giedo, Geoffrey Evans, and Nan Dirk de Graaf(2013). 'Class voting and Left-Right party positions: A comparative study of 15 Western democracies, 1960-2005', Social Science Research, 42:2, 376-400.

Klüver, Heike, and Jae-Jae Spoon (2016). 'Who Responds? Voters, Parties and Issue Attention', British Journal of Political Science, 46:3, 633-654.

Kosmidis, Syros, Sara Hobolt, Andrew Molloy, and Stephen Whitefield (2018). 'Party competition and emotive rhetoric', Comparative Political Studies, 1-39.

Laakso, Markku, and Rein Taagepera (1979). "“Effective” Number of Parties A Measure with Application to West Europe', Comparative Political Studies, 12:1, 3-27.

Lachat, Romain (2008). 'The impact of party polarization on ideological voting', Electoral Studies, 27:4, 687-698.

Laver, Michael, Kenneth Benoit, and John Garry (2003). 'Extracting Policy Positions from Political Texts Using Words as Data', The American Political Science Review, 97:2, 311331.

Laver, Michael, and Ian Budge (1992). Party Policy and Government Coalitions. New York: St. Martin's Press.

Lefkofridi, Zoe, Nathalie Giger, and Aina Gallego (2014). 'Electoral Participation in Pursuit of Policy Representation: Ideological Congruence and Voter Turnout', Journal of Elections, Public Opinion and Parties, 24:3, 291-311.

Lijphart, Arend (1997). 'Unequal Participation: Democracy's Unresolved Dilemma', The American Political Science Review, 91:1, 1-14.

Lupu, Noam (2015). 'Party Polarization and Mass Partisanship: A Comparative Perspective', Political Behavior, 37:2, 331-356.

Matakos, Konstantinos, Orestis Troumounis, and Dimitrios Xefteris (2016). 'Electoral Rule Disproportionality and Platform Polarization', American Journal of Political Science, 60, 1026-1043. 
McDonald, Michael D, and Silvia M. Mendes (2001). 'Checking the Party Policy Estimates: Convergent Validity', in Hans-Dieter Klingemann, Andrea Volkens, Judith Bara, and Eric Tanenbaum (eds.), Mapping Policy Preferences: Estimates for Parties, Electors, and Governments 1945-1998. Oxford: Oxford University Press, 127-142.

Mellon, Jonathan, and Christopher Prosser (2017). 'Missing Nonvoters and Misweighted Samples: Explaining the 2015 Great British Polling Miss', Public Opinion Quarterly, 81:3, 661-687.

Merrill, Samuel, and James Adams (2002). 'Centrifugal Incentives in Multi-Candidate Elections', Journal of Theoretical Politics, 14:3, 275-300.

Merrill, Samuel, Bernard Grofman, and James Adams (2001). 'Assimilation and contrast effects in voter projections of party locations: Evidence from Norway, France, and the USA', European Journal of Political Research, 40:2, 199-221.

Milazzo, Caitlin, James Adams, and Jane Green (2012). 'Are Voter Decision Rules Endogenous to Parties' Policy Strategies? A Model with Applications to Elite Depolarization in PostThatcher Britain', The Journal of Politics, 74:1, 262-276.

Nickell, Stephen (1981). 'Biases in Dynamic Models with Fixed Effects', Econometrica, 49, 14171426.

Peters, Yvette, and Sander Ensink (2015). 'Differential Responsiveness in Europe: The Effects of Preference Difference and Electoral Participation', West European Politics, 38:3, 577-600.

Pitkin, Hanna F. (1967). The Concept of Representation. Berkeley, CA: University of California Press.

Plümper, Thomas, Vera E. Troeger, and Philip Manow (2005). 'Panel data analysis in comparative politics: Linking method to theory', European Journal of Political Research, 44:2, 327-354.

Powell, G. Bingham (2009). 'The Ideological Congruence Controversy: The Impact of Alternative Measures, Data, and Time Periods on the Effects of Election Rules', Comparative Political Studies, 42:12, 1475-1497.

Schlozman, Kay Lehman, Sidney Verba, and Henry E. Brady (2012). The unheavenly chorus: unequal political voice and the broken promise of American democracy. Princeton, NJ: Princeton University Press.

Schumacher, Gijs, Catherine E. de Vries, and Barbara Vis (2013). 'Why Do Parties Change Position? Party Organization and Environmental Incentives', The Journal of Politics, 75:02, 464-477. 
Steiner, Nils D., and Christian W. Martin (2012). 'Economic Integration, Party Polarisation and Electoral Turnout', West European Politics, 35:2, 238-265.

Volkens, Andrea, Pola Lehmann, Theres Matthie, Nicolas Merz, Sven Regel, and Bernhard Wessels (2017). The Manifesto Data Collection. Manifesto Project. Version 2017a [Dataset]. Berlin: Berlin Social Science Center (WZB). Retrieved from https://doi.org/10.25522/manifesto.mpds.2017a (accessed 12 January 2018).

Ward, Hugh, Lawrence Ezrow, and Han Dorussen (2011). 'Globalization, Party Positions, and the Median Voter', World Politics, 63:3, 509-547.

Wessels, Bernhard, and Hermann Schmitt (2008). 'Meaningful choices, political supply, and institutional effectiveness', Electoral Studies, 27:1, 19-30. 